Research Article

\title{
EFFECT OF WATER DEFICIT AT VEGETATIVE AND REPRODUCTIVE STAGES OF HYBRID, OPEN POLLINATED VARIETY AND LOCAL MAIZE (Zea mays L.)
}

\author{
S. K. Sah ${ }^{1}$ and O. B. Zamora ${ }^{2}$ \\ ${ }^{1}$ Institute of Agriculture and Animal Sciences, Rampur, Chitwan, Nepal \\ ${ }^{2}$ University of the Philippines at Los Baños
}

\begin{abstract}
A pot experiment was conducted to study the effects of water deficit on vegetative and reproductive stages of Hybrid, Open pollinated (OPV) and Local varieties of maize. Water deficit at vegetative stage significantly reduced plant height, leaf area, shoot dry matter, root dry matter of the upper $25 \mathrm{~cm}$ depth, kernel number and grain yield per plant as compared to well watered plant. Water deficit at reproductive stage reduced more leaf area, kernel number and grain yield per plant than water deficit at vegetative stage. Water deficit at reproductive stage also reduced shoot dry matter, kernel size and harvest index. Leaf water potential and relative water content taken at 58 and 60 days after planting were also reduced by water deficit. The Local variety was taller with smaller kernel size and lower harvest index than Open pollinated and Hybrid varieties. There were no significant interactions among the varieties and water deficit treatments.
\end{abstract}

Key words: Leaf water potential, relative water content, vegetative and reproductive stages, harvest index

\section{INTRODUCTION}

Maize is the second important crop of Nepal after rice in terms of cultivated area and amount of production (CBS, 2004). Maize crop requires about 400 to 600 millimeters of water during its lifecycle (Singh, 1991). Water deficit at any growth stage reduces the growth and productivity of crops. Paudyal et al. (2001) identified water stress as one of the major problems of the spring season maize in most parts of Terai region of Nepal. The effect of water deficit on growth and yield depends upon time, intensity and duration of water deficit (Classen and Shaw, 1970a). It is necessary to know such effects of water deficit at different stages of crop growth in order to develop crop management strategies to minimize the risk in maize production. Therefore, this study was conducted to determine the effects of water deficit at vegetative and reproductive stages on growth and productivity of maize.

\section{MATERIALS AND METHODS}

The experiment was conducted from March to June 2003 in the Department of Agronomy, University of the Philippines at Los Baños. The experiment was laid out in two factors factorial randomized complete block design with three replications. The treatment combinations consisted of 3 levels of water stress, viz. $W_{1}-w_{e}$ watered throughout the lifecycle, $\mathrm{W}_{2}$ - water stress at vegetative stage, in which water was withheld from 32-40 days after planting (DAP), $W_{3}$ - water stress at reproductive stage, in which water was withheld from 52-60 DAP; and three varieties of maize, viz. $V_{1}$ - Local variety (Tiniguib), $V_{2}$ - Open pollinated variety (IPB var 7), $V_{3}$ - Hybrid variety (IPB 911). The mean maximum temperature during crop growing period ranged from $32.3^{\circ} \mathrm{C}$ to $34.9^{\circ} \mathrm{C}$ and mean minimum temperature ranged from $22.1^{\circ} \mathrm{C}$ to $24.5^{\circ} \mathrm{C}$. The relative humidity during crop growing period ranged from $77 \%$ to $85 \%$. The pots were transferred to green house during rainy days. All the varieties were harvested in 95 days.

Total one hundred eight polyvinyl chloride (PVC) pots measuring $75 \mathrm{~cm}$ depth and $20 \mathrm{~cm}$ internal diameter lined with polythene sheet and filled with well pulverized soil up to brim of the pots were used in the experiment. Each pot was fertilized with $6 \mathrm{~g}$ complete fertilizer and $2 \mathrm{~g}$ urea. Each replication had four PVC pots planted with three seeds, which was thinned to one plant per pot after 15 days of planting. All pots were irrigated daily to maintain optimum moisture for 31 days. Irrigation was withheld from 32 to 40 DAP to impose water stress at vegetative stage. Similarly, irrigation was withheld from 52 to 60 DAP to impose water stress at reproductive stage. After water stress period, crop was irrigated daily to optimum moisture condition. Twenty-seven plants, 
i.e. from each replication was sampled at 47 and 67 DAP for measuring plant height, leaf area, shoot dry matter and root dry matter. The remaining 54 plants, i.e. two from each replication were used for determining yield components. Leaf water potential was measured with pressure bomb apparatus in the second leaf from the youngest at $58 \mathrm{DAP}$ at 10:00 hr. Leaf discs were taken at 60 DAP at 10:00 hr. to determine the relative water content of leaf.

Polythene lining with soil and roots was removed from each pot during each sampling. The soil with roots was cut with sharp knife from $0-25 \mathrm{~cm}, 25-50 \mathrm{~cm}$, and $50-75 \mathrm{~cm}$ depth. The mass was passed through $2.5 \mathrm{~mm}$ sieve and washed with water. The extracted roots of each layer were oven dried at $60^{\circ} \mathrm{C}$ for one week and dry matter of each layer was determined.

\section{RESULTS AND DISCUSSION}

\section{Plant height}

There was significant difference in plant height among the varieties (Table 1). Local variety (Tiniguib) was taller than OPV (IPB var 7) and Hybrid variety (IPB 911) at both dates of observation. The OPV was also significantly taller than Hybrid at 47 DAP.

Water stress at vegetative stage significantly reduced the plant height as compared to well-watered treatment, whereas water stress at reproductive stage did not influence the plant height significantly as compared to wellwatered treatment (Table 1). The reduction in plant height is common with consistent reaction to water stress. Nesmith and Ritche (1992) also observed decline in the extension of stem and leaf, and reduction in inter nodal length of corn in response to pre- anthesis water deficit.

\section{Leaf area}

Leaf area per plant was the highest in the Hybrid variety followed by the Local variety and the OPV but it was not significantly different among the varieties at both dates of observation (Table 1). Water stress at vegetative as well as reproductive stage significantly reduced the leaf area per plant as compared to well-watered plant (Table 1). The reduction in leaf area per plant due to water stress at vegetative stage was $15 \%$ and it was 33\% due to water stress at reproductive stage as compared to well-watered plants. The reduction of leaf area in response to water stress at vegetative stage is due to decrease in turgor pressure, which is necessary for cell enlargement. Acevedo et al. (1971) reported that elongation of maize leaves was highly sensitive to slight reduction in soil and leaf water potential. Higher reduction of leaf area per plant due to water stress at reproductive stage might be due to accelerated leaf senescence at low leaf water potential. Aparicio- Tejo and Boyer (1983) also observed accelerated leaf drying in maize due to low water potential.

\section{Shoot dry matter}

Shoot dry matter of the Local variety was significantly higher than the OPV but it was not different from the Hybrid variety at 47 DAP. Similarly, shoot dry matter of the Hybrid variety was significantly higher than the OPV but it was not different from the Local variety at 67 DAP. The shoot dry matter at harvest (95 DAP) was not significantly different among the varieties (Table 1).

Water stress at vegetative as well as reproductive stage reduced the shoot dry matter significantly as compared to well-watered plants. Final shoot dry matter at harvest (95 DAP) was also significantly reduced due to water stress at vegetative and reproductive stages. The reduction of final shoot dry matter was $17 \%$ due to stress at vegetative stage and $15 \%$ due to stress at reproductive stage as compared to well-watered plants.

Water stress influenced the height and leaf area per plant, which ultimately influenced the shoot dry matter of plants. Reductions of photosynthetic surface by water stress decreased the ability of plants to produce dry matter. This result is similar to the results obtained by Classen and Shaw (1970a).

\section{Root dry matter}

There was significant difference in root dry matter per plant among the varieties in the $25-75 \mathrm{~cm}$ depth but not in $0-25 \mathrm{~cm}$ depth at $47 \mathrm{DAP}$. Local variety (Tiniguib) had significantly higher root dry matter per plant in 25-75 cm depth as compared to Hybrid (IPB 911) but at par with OPV (Table 2). At 67 DAP, the root dry 
matter of Hybrid was higher than OPV but at par with Local variety in the $0-25 \mathrm{~cm}$ depth. The root dry matter of Local variety was higher than both Hybrid and OPV in 25-75 cm depth at 67 DAP. Gardner et al. (1985) mentioned the large genotypic difference in the rooting ability of crop. Higher root content at lower depth provides the ability of crop to survive under drought by acquiring more water.

Table 1. Effects of treatments on vegetative growth

\begin{tabular}{|c|c|c|c|c|c|c|c|}
\hline \multirow[t]{2}{*}{ Treatments } & \multicolumn{2}{|c|}{ Plant height $(\mathrm{cm})$} & \multicolumn{2}{|c|}{ Leaf area per plant $\left(\mathrm{cm}^{2}\right)$} & \multicolumn{3}{|c|}{ Shoot dry matter (g) } \\
\hline & 47DAP & 67DAP & 47DAP & 67DAP & 47DAP & 67DAP & 95DAP \\
\hline \multicolumn{8}{|l|}{ Varieties } \\
\hline Hybrid (IPB 911) & $145.00 \mathrm{c}$ & $160.66 \mathrm{~b}$ & $3687.4 \mathrm{a}$ & $2536.8 \mathrm{a}$ & $68.52 \mathrm{ab}$ & $99.65 \mathrm{a}$ & $120.68 \mathrm{a}$ \\
\hline OPV (IPB var 7) & $161.68 \mathrm{~b}$ & $165.00 \mathrm{~b}$ & $3209.1 \mathrm{a}$ & $2224.7 \mathrm{a}$ & $63.29 \mathrm{a}$ & $86.16 \mathrm{~b}$ & $120.09 \mathrm{a}$ \\
\hline Local (Tiniguib) & $180.30 \mathrm{a}$ & $189.44 a$ & $3510.8 \mathrm{a}$ & $2399.3 \mathrm{a}$ & $73.28 \mathrm{a}$ & $89.56 \mathrm{ab}$ & $116.50 \mathrm{a}$ \\
\hline \multicolumn{8}{|l|}{ Water Stress } \\
\hline Water stress (32-40DAP) & $144.90 \mathrm{~b}$ & $160.66 \mathrm{~b}$ & $3053.1 \mathrm{~b}$ & $2818.2 \mathrm{a}$ & $54.18 \mathrm{~b}$ & $82.86 \mathrm{~b}$ & $110.87 \mathrm{~b}$ \\
\hline Water stress (52-60DAP) & $170.67 \mathrm{a}$ & $172.66 \mathrm{ab}$ & $3738.7 \mathrm{a}$ & $1739.1 \mathrm{~b}$ & $76.99 \mathrm{a}$ & $85.02 \mathrm{~b}$ & $113.49 \mathrm{~b}$ \\
\hline Well watered (Control) & $171.44 a$ & $181.55 \mathrm{a}$ & $3615.6 \mathrm{a}$ & $2603.4 \mathrm{a}$ & $73.92 \mathrm{a}$ & $107.5 \mathrm{a}$ & $132.91 \mathrm{a}$ \\
\hline
\end{tabular}

Treatment means followed by common letters in column are not significantly different within varieties and water stress treatments, respectively, by LSD at 0.05

Water stress at vegetative stage significantly reduced the root dry matter per plant in $0-25 \mathrm{~cm}$ depth but there was no influence on root dry matter per plant due to water stress at reproductive stage (Table 2). Cruz et al. (1986) observed in rice that mild water stress at vegetative stage significantly reduced the total root dry matter as well as root length density. In this experiment, root dry matter per plant of stressed plant was similar to well watered plant in the lower depth. Plant generally maintains its root growth to acquire water from lower depth under water stress condition. Sharp and Davis (1979) observed significant accumulation of solutes in the root tips of un-watered plants which resulted in the maintenance of root turgor for the duration of water stress treatment. Water stress at reproductive stage did not influence the root dry matter per plant either at $0-25 \mathrm{~cm}$ depth or at $25-75 \mathrm{~cm}$ depth. When water was reapplied after stress at vegetative stage, the root dry matter per plant recovered at the second date of observation. In determinate crops, active growth of roots and leaves takes place in the vegetative stage. This might be the reason for no influence on root dry matter per plant due to water deficit at reproductive stage.

\section{Leaf water potential (LWP) and relative water content (RWC)}

LWP and RWC were taken at 58 and 60 DAP, respectively, to understand plant water condition during water deficit period. There was no difference in LWP and RWC among the varieties. Water stress at reproductive stage significantly lowered the LWP and RWC as compared to well-watered plants (Table 3). LWP and RWC were similar in well-watered plants and water stress at vegetative stage because at the time of observation both treatments were equally supplied with water.

Low LWP, which is developed due to water deficit, has been reported to decrease the leaf growth rate and leaf area development (Acevedo et al., 1971), inhibit dry matter accumulation and accelerate leaf senescence (Aparicio- Tejo and Boyer, 1983), decrease photosynthesis (Westgate and Boyer, 1985), decrease the synchronization of male and female floral development (Herrero and Johnson, 1981), increase frequency of zygotic abortion (Zinselmeir et al., 1995), decrease grain number, size and yield (Saini and Westgate, 2000). RWC is integrated measure of plant water status. Higher RWC is necessary for proper growth and function of plant (Blum, 1999). In the present experiment, low RWC due to water stress inhibited growth and plant function, which were reflected in lower leaf area, shoot dry matter and lower yield. 
Table 2: Effect of treatments on root dry matter

\begin{tabular}{|c|c|c|c|c|}
\hline \multirow[t]{3}{*}{ Treatments } & \multicolumn{4}{|c|}{ Root dry matter per plant (g) } \\
\hline & \multicolumn{2}{|c|}{47 DAP } & \multicolumn{2}{|c|}{67 DAP } \\
\hline & $\begin{array}{l}0-25 \mathrm{~cm} \\
\text { depth }\end{array}$ & $\begin{array}{l}25-75 \mathrm{~cm} \\
\text { depth }\end{array}$ & $\begin{array}{l}0-25 \mathrm{~cm} \\
\text { depth }\end{array}$ & $\begin{array}{l}25-75 \mathrm{~cm} \\
\text { depth }\end{array}$ \\
\hline \multicolumn{5}{|l|}{ Varieties } \\
\hline Hybrid (IPB 911) & $18.56 \mathrm{a}$ & $5.27 \mathrm{~b}$ & $18.77 \mathrm{a}$ & $6.43 b$ \\
\hline OPV (IPB var 7) & $18.43 \mathrm{a}$ & $6.11 \mathrm{ab}$ & $14.31 \mathrm{~b}$ & $6.62 \mathrm{~b}$ \\
\hline Local (Tiniguib) & $17.10 \mathrm{a}$ & $7.79 \mathrm{a}$ & $16.35 \mathrm{ab}$ & $9.04 \mathrm{a}$ \\
\hline \multicolumn{5}{|l|}{ Water stress } \\
\hline Water stress (32 - $40 \mathrm{DAP})$ & $11.37 \mathrm{~b}$ & $5.74 \mathrm{a}$ & $17.42 \mathrm{a}$ & $6.97 \mathrm{a}$ \\
\hline Water stress $(52-60 \mathrm{DAP})$ & $20.65 a$ & $6.67 \mathrm{a}$ & $17.08 \mathrm{a}$ & $8.03 \mathrm{a}$ \\
\hline Well watered (control) & $22.07 \mathrm{a}$ & $6.76 \mathrm{a}$ & $14.93 \mathrm{a}$ & $7.01 \mathrm{a}$ \\
\hline
\end{tabular}

Treatment means followed by common letters in column are not significantly different within varieties and water stress treatments, respectively, by LSD at 0.05 .

Table 3: Effects of treatments on leaf water potential at $58 \mathrm{DAP}$ and relative water content at $60 \mathrm{DAP}$

\begin{tabular}{|lll|}
\hline Treatments & Leaf Water Potential (Mpa) & Relative Water Content (\%) \\
\hline Varieties & $-1.43 \mathrm{a}$ & $76.61 \mathrm{a}$ \\
Hybrid (IPB 911) & $-1.46 \mathrm{a}$ & $79.69 \mathrm{a}$ \\
OPV (IPB var 7) & $-1.37 \mathrm{a}$ & $80.79 \mathrm{a}$ \\
Local (Tiniguib) & & \\
Water stress & $-1.30 \mathrm{~b}$ & $82.53 \mathrm{a}$ \\
Water stress (32-40 DAP) & $-1.70 \mathrm{a}$ & $72.39 \mathrm{~b}$ \\
Water Stress (52- 60 DAP) & $-1.26 \mathrm{~b}$ & $82.15 \mathrm{a}$ \\
\hline Well watered (Control) & & \\
\hline
\end{tabular}

Means followed by common letter in column are not significantly different within varieties and water stress treatments, respectively, by LSD at 0.05 level

Table 4: Effect of treatments on yield attributes and harvest index

\begin{tabular}{|lllll|}
\hline Treatments & $\begin{array}{l}\text { Kernel } \\
\text { Per cob }\end{array}$ & $\begin{array}{l}100 \text { kernel } \\
\text { weight (g) }\end{array}$ & $\begin{array}{l}\text { Grain yield } \\
\text { per plant (g) }\end{array}$ & $\begin{array}{l}\text { Harvest } \\
\text { index }\end{array}$ \\
\hline Varieties & & & & $0.286 \mathrm{a}$ \\
Hybrid (IPB 911) & $184.22 \mathrm{a}$ & $19.29 \mathrm{a}$ & $38.68 \mathrm{a}$ & $0.312 \mathrm{a}$ \\
OPV (IPB var 7) & $185.11 \mathrm{a}$ & $19.16 \mathrm{a}$ & $35.56 \mathrm{a}$ & $0.224 \mathrm{~b}$ \\
Local (Tiniguib) & $195.22 \mathrm{a}$ & $14.06 \mathrm{~b}$ & $26.33 \mathrm{~b}$ & $0.308 \mathrm{a}$ \\
Water stress & & & & $0.193 \mathrm{~b}$ \\
Water stress (32- 40 DAP) & $191.44 \mathrm{~b}$ & $18.07 \mathrm{a}$ & $34.89 \mathrm{~b}$ & $0.321 \mathrm{a}$ \\
Water stress (52-60 DAP) & $139.33 \mathrm{c}$ & $15.90 \mathrm{~b}$ & $22.30 \mathrm{c}$ & $43.38 \mathrm{a}$ \\
Well watered (Control) & $233.78 \mathrm{a}$ & $18.54 \mathrm{a}$ & & \\
\hline
\end{tabular}

Means followed by common letters are not significantly different within the varieties and water stress treatments, respectively, by LSD at 0.05 level

\section{Kernel number}

Water stress treatments significantly influenced the kernel number per cob (Table 4). Water deficit at vegetative and reproductive stage reduced the kernel number per cob by $18 \%$ and $40 \%$, respectively, as compared to well-watered plants. There was no significant difference in kernel number per cob among the varieties.

Water stress reduces the kernel number per cob well before the onset of reproductive stage. Nesmith and 
Ritchie (1992) also observed a decline in kernel number per cob due to pre-anthesis water deficit. Kernel number per cob is the most sensitive to water deficit at reproductive stage. Reproductive stage drought can cause asynchrony between pollen shedding and silk emergence, and thus, results failure of pollination (Herrero and Johnson, 1981). Lower water potential at early silk emergence stage reduces the assimilate supply because of inhibition of photosynthesis, which may cause low seed number (Westgate and Boyer, 1985). It may also cause zygotic abortion (Westgate and Boyer, 1986) resulting in lower grain number per cob.

\section{Kernel size}

Hundred kernel weight was significantly different among the varieties (Table 4). The kernel size of Local variety was significantly lower than Hybrid and OPV, which did not differ significantly from each other. Water deficit at reproductive stage significantly reduced the kernel size as compared to well watered plants (Table 4). The reduction in kernel size was $14 \%$ due to water deficit at reproductive stage.

Water deficit at reproductive stage accelerates the leaf senescence, inhibits photosynthesis, reduces the assimilate supply, and thus, decreases the rate and duration of grain filling. Setter et al. (2001) also reported that pre-pollination and post-pollination water deficit reduce the kernel number and kernel size of the corn.

\section{Grain yield}

Grain yield per plant differed among the varieties and was affected by water deficit (Table 4). The grain yield per plant of the Local variety was significantly lower than OPV and Hybrid variety. The lower yield of Local variety was due to smaller grains and lower harvest index as compared to OPV and Hybrid variety. Water deficit at vegetative as well as reproductive stages significantly reduced the grain yield per plant as compared to well-watered plant (Table 4). The reduction was $19.5 \%$ and $48.5 \%$ due to water deficit at vegetative and reproductive stages, respectively, as compared to well watered plants. The reduction in grain yield was due to loss of grain number in vegetative stage drought, whereas it was due to less grain number and lower grain size in water deficit at reproductive stage. Classen and Shaw (1970b) also observed significant grain yield reduction $(12-15 \%)$ due to water deficit at vegetative stage and $53 \%$ grain yield reduction due to water deficit at $75 \%$ silking stage.

\section{Harvest index}

The harvest index of the Local variety was significantly lower than OPV and Hybrid varieties (Table 4). The genotypic differences in harvest index exist. Traditional varieties generally have lower harvest index. Water deficit at reproductive stage significantly reduced the harvest index, whereas there was no significant difference in the harvest index between plants having water deficit at vegetative stage and well watered plants (Table 4). The lower harvest index due to drought at reproductive stage indicates less partitioning of dry matter towards the grain. Sinclair et al. (1990) reported that under moderate water stress, harvest index was stable but decreased under severe water stress, where accumulated biomass was less than about $1100 \mathrm{~g} \mathrm{~m}^{-2}$.

\section{CONCLUSIONS}

Water deficit at reproductive stage was more sensitive than water deficit at vegetative stage. The reduction in grain yield per plant was higher in water deficit at reproductive stage because of higher reduction of leaf area, kernel number and kernel weight as compared to water deficit at vegetative stage.

\section{ACKNOWLEDGEMENTS}

The authors are grateful to World Bank/AERP project for providing financial support for conducting the research. The authors are also thankful to Prof. Dr. Resham Bahadur Thapa, Director, Directorate of Research and Publications, IAAS for the critical review of the paper and suggestion for the improvement.

\section{REFERENCES CITED}

Acevedo, E., T. C. Hasio, and D. W. Henderson. 1971. Immediate and subsequent growth response of maize leaves to changes in water status. Plant Physiol. 48:631-636.

Aparicio- Tejo, P. M. and J. S. Boyer. 1983. Significance of accelerated leaf senescence at low water potential for water loss and grain yield in maize. Crop Sci. 23: 1198- 1201. 
Blum, A. 1999. Towards standards assays of drought resistance in crop plants. Proc. Workshop held in CIMMYT, June 21-25, 1999. pp. 29 - 35.

CBS, 2004. Statistical pocket book. His Majesty Government, National Planning Commission Secretariat, Thapathali, Ramsah Path, Kathmandu, Nepal. pp. 50 - 85.

Classen, M. M. and R. H. Shaw. 1970 a. Water deficit on corn I. Vegetative components. Agron. J. 62: 649-651.

Classen, M. M. and R. H. Shaw. 1970b. Water deficit on corn I. Grain components. Agron. J. 62: 652-654.

Cruz, R. T. , J. C. O. Toole, M. Dingkuin, E. B. Yamboo, M. Thangaraj and S. K. Datta. 1986. Shoot and root responses to water deficits in rainfed lowland rice. Aust. J. Plant Physiol. 13:279-282.

Gardner, F. P., R. B. Pearce and R.L. Mitchell.1985. Physiology of crop plants. Iowa State University Press. Iowa, USA.

Herrero, M. P. and R. R. Johnson. 1981. Drought stress and its effects on maize reproductive systems. Crop Sci. 21: 105- 109.

Nesmith, D. S. and J. T. Ritchie. 1992. Short and long term response of corn to pre-anthesis soil water deficit. Agron. J. 84:107- 113.

Paudyal, K.R., J.K. Ransom, N. P. Rajbhandari, K. Adhakari, R.V. Gerpacio and P. L. Pingali. 2001. Maize in Nepal, Production systems, constraints and priorities for research. Kathmandu: NARC and CIMMYT. 48 p.

Saini, H. S. and M. E. Westgate. 2000. Reproductive development in grain crops during drought. Adv. Agron. 68: 61-95.

Setter, T. L., B. A. Flannigan and J. Melkonian.2001. Loss of kernel set due to water deficit and shade in maize; carbohydrate supplies; abescisic acid and cytokinins, Crop Sci. 41:1530-1540.

Sharp, R. E. and W.J. Davis. 1979. Solute regulation and growth of roots and shoots of water stressed maize plants. Planta.147: 43-49.

Sinclair, T. R., J. M. Bennet and R. C. Muchow. 1990. Relative sensitivity of grain yield and biomass accumulation to drought in field grown maize. Crop Sci. 25: 690-693.

Singh, C.1991. Maize. Modern techniques of raising field crops. Oxford and IBH Publishing Co., Pvt. Ltd., New Delhi. P. 88.

Westgate, M. E. and J. S. Boyer.1985. Carbohydrate reserves and reproductive development at low leaf water potential in maize. Crop Sci. 25:762-769.

Westgate, M. E. and J.S. Boyer. 1986. Reproduction at low silk and pollen water potentials in maize. Crop Sci. 26: 951-956.

Zinselmeir, C., M. E. Westgate and R. J. Jones. 1995. Kernel set at low water potential does not vary with source/ sink ratio in maize. Crop Sci. 35: 158-163. 